
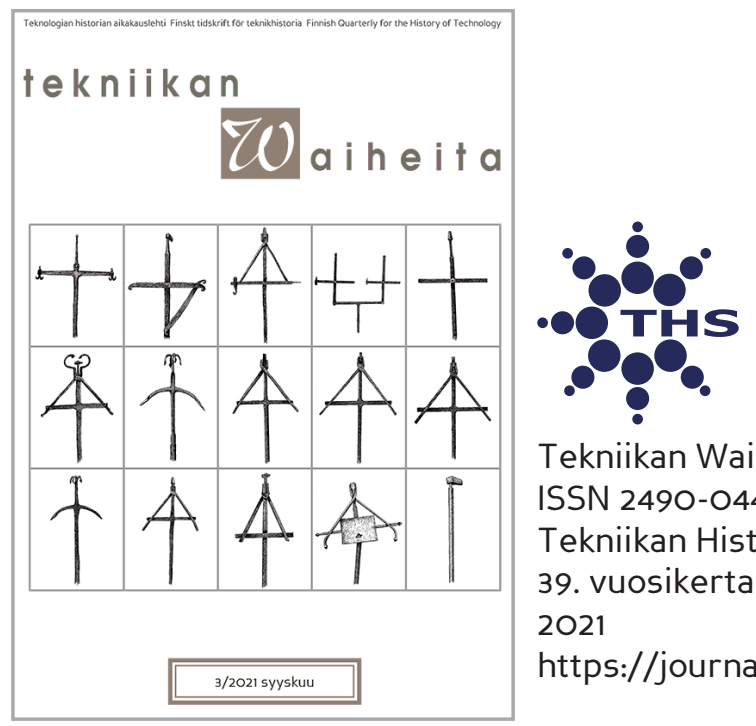

Tekniikan Waiheita

ISSN 2490-0443

Tekniikan Historian Seura ry.

39. vuosikerta: 3

2021

https://journal.fi/tekniikanwaiheita

\title{
Miilunpoltosta ja hiilimiiluista Suomessa
}

Janne Kangaskesti

To cite this article: Janne Kangaskesti, "Miilunpoltosta ja hiilimiiluista Suomessa" Tekniikan Waiheita 39, no. 3 (2021): 140-159. https://doi.org/10.33355/tw.109938

To link to this article: https://doi.org/10.33355/tw.109938 


\title{
Miilunpoltosta ja hiilimiiluista Suomessa
}

\author{
Janne Kangaskesti
}

Puuhiilen valmistaminen on jäänyt vähemmälle huomiolle arkeologian piirissä viime aikoihin saakka. Ala on kuitenkin ollut historiallisesti merkittävä ja jättänyt runsaasti jälkiä myös Suomen metsiin. Esimerkiksi yhden kankirautatonnin valmistaminen rautamalmista ruukissa on vaatinut arviolta kuusi tonnia puuhiiltä. ${ }^{2} 1700$-luvulla Ruotsissa kankiraudan tuotantokuluista yli puolet koostui puuhiilen tuotannosta. ${ }^{3}$ Kankiraudan jatkojalostaminen on vaatinut lisää puuhiiltä ja samoin sitä on tarvittu muun muassa sepäntöissä ja lasinvalmistuksessa. Hiilentarve on ollut huomattava vuosisatojen ajan, sillä kivihiilen laajamittaisen käytön mahdollistaneet menetelmät yleistyvät vasta 1800-luvun kuluessa. ${ }^{4}$ Suomen rautateollisuuden synty 1600-luvulla perustui osin ajatukseen metsäisestä Suomesta hyvänä puuhiilentuotannon alueena, sillä Ruotsin valtakunnassa puuhiilen - joka murenee herkästi kuljetuksessa - saatavuus nousi usein raudantuotannon pullonkaulaksi ruukkien lähimetsien ehtyessä. ${ }^{5}$

Puuhiilen tuotanto nojasi Suomessa lähes yksinomaan miilunpolton varaan aina 1800-luvun puoliväliin asti, jolloin ruukeissa otettiin käyttöön hiiliuuneja. Lisäksi tervanpolton yhteydessä on voitu ottaa talteen hiiltä tervahaudasta vähäisempään tarpeeseen. Uuni- ja kivihiilen käytön yleistyttyäkin miilunpoltto piti pintansa, yleistyen hetkellisesti sota-aikoina, kunnes hävisi lopulta elinkeinona 1950-luvulla. ${ }^{6}$

Tämä artikkeli on katsaus miilunpolttoon ja miilunpohjiin muinaisjäännöksinä, pohjautuen pro gradu -tutkielmaani Se syntyi sysimäellä, kasvoi biilikankahalla - biilimïlujen arkeologiset jäännökset Suomessa (2019). Olen tiivistänyt ja lyhennellyt gradussani esitettyä sekä päivittänyt joitakin osuuksia. Aiheen tutkimus on viime vuosina aktivoitunut erityisesti Ruotsissa, mutta myös muualla Euroopassa ja Pohjois-Amerikassa. Erityisesti uusilla teknologisilla menetelmillä on ollut iso merkitys tutkimukselle, joista merkittävimpänä laserkeilaus- eli Lidarkaukokartoitusaineiston saatavuuden parantuminen. Tekoälyalgoritmit ovat myös tuloillaan laserkeilausaineiston analysoinnin avuksi. Ennen kehittyneiden menetelmien soveltamista on kuitenkin oltava käsitys siitä, millaista ilmiötä tarkalleen ottaen tutkitaan.

\section{Mikä on miilu?}

Miilu on Kielitoimiston sanakirjan mukaan "havuilla, mullalla ja turpeella peitetty puukeko, jossa puut poltetaan puuhiiliksi eli sysiksi” (Kuva 1). ${ }^{7}$ Mainitussa polttamisessa on tarkalleen ottaen kyse puun pyrolyysistä eli kuivatislaamisesta orgaanisen materiaalin kuumetessa riit-

\footnotetext{
${ }^{1}$ Kirjoittaja on historiallisesta ajasta ja Itä-Suomesta kiinnostunut arkeologi.

${ }^{2}$ Arpi 1953, 25.

${ }^{3}$ Hennius 2019, 10.

${ }^{4}$ Hennius 2019, 6, 11

${ }^{5}$ Arpi 1953, 25; Vilkuna 1994, 21, 22.

${ }^{6}$ Bergroth 1885, 1, 9, 10; Ekman 1937; Laine 1948, 259; Niukkanen 2009, 41, 42.

${ }^{7}$ Kielitoimiston sanakirja 2020, www.kielitoimistonsanakirja.fi.
} 


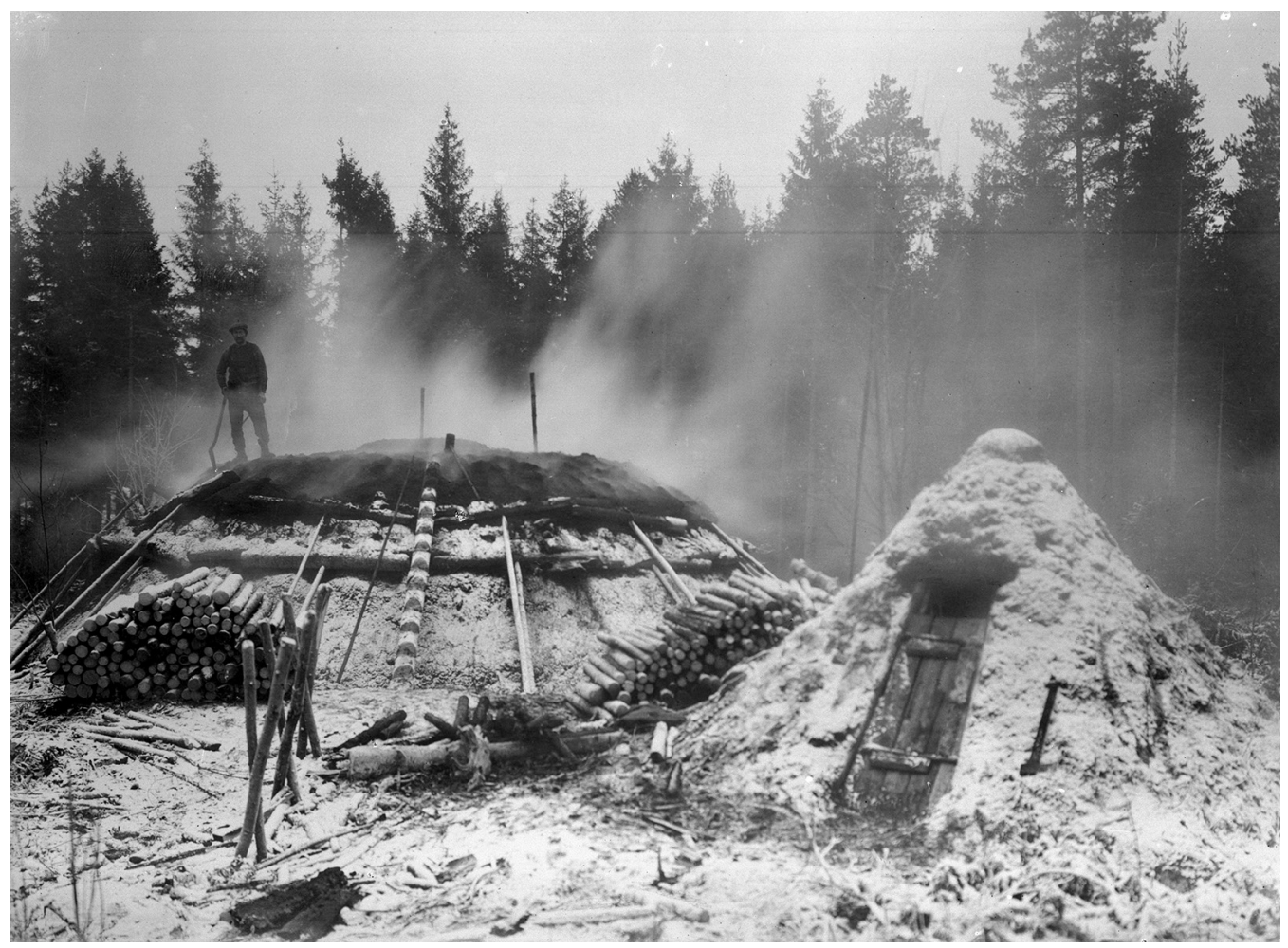

Kuva 1. Pystymiilua poltetaan Ruotsissa vuonna 1918. Etuoikealla miilunpolttajien maja. Kuva: Lindskog, Samuel / Örebro läns museum (CC PDM).

tävästi hapettomissa olosuhteissa. Maapeitteen tarkoitus on säädellä palamisreaktion hapensaantia, ettei liian suuri osa puusta pala tuhkaksi asti. ${ }^{8}$

Toisinaan miilu-sanaa on käytetty myös tervahaudasta (tervamiilu), mikä on perusteltua tervahaudan rakennetta ajatellen, mutta voi johtaa sekaannuksiin. Vastaavasti yksi hiilimiilujen tyypeistä, kuoppamiilu eli (sysi- tai) hiilihauta, voi joskus nimensäkin puolesta sekoittua tervahautaan. Valtaosaa miiluista ei kuitenkaan ole rakennettu kuoppaan, kun taas tervahaudat ovat aina painanteita. Suomessa arkeologien piirissä sanasekaannusta aiheuttaa myös miilu-sanan käyttäminen miilunpoltosta muodostuneesta jäännöksestä. Kyseistä kohdetta voi nimittää vaihtoehtoisesti miilunpohjaksi (en kolbotten tai en milbotten) ruotsalaisten arkeologien käytäntöä noudattaen. ${ }^{9}$ Käytäntö selventää mistä useimmissa miilunjäännöksissä on pääasiassa kyse. Varsinainen miilu puretaan onnistuneen polton lopuksi.

Miilut voi jakaa kolmeen päätyyppiin, joita kaikkia on käytetty Suomessa, eli pysty-, lama- ja kuoppamiiluihin. Pystymiilut ovat kaikista yleisin ja Euroopassa laajimmin käytössä ollut tyyppi. Lamamiiluja on rakennettu erityisesti Ruotsissa ja Itävallassa, mutta Suomen alueelta niitä tunnetaan vähän. Kuoppamiiluihin lukeutuu rakenteeltaan vaihtelevia, yleensä

\footnotetext{
${ }^{8}$ Talvitie 1924, 46; Scott \& Damblon 2010, 2.

${ }^{9}$ Esim. Hennius 2019.
} 
sangen yksinkertaisia ja pienikokoisia miiluja, mistä johtuen tyyppi on usein tulkittu kaikkein varhaisimmaksi miilumuodoksi. Miilujen luokittelu perustuu polttopuiden asetteluun. Pystymiilussa puut on aseteltu pystyyn keskustukin ympärille, lamamiilussa vuorostaan vaakaan paalukehikon tukemana. Molemmat miilutyypit on rakennettu maan pinnalle, toisin kuin kuoppamiilut. Kuoppamiiluissa puut on aseteltu yleensä vaakatasoon. ${ }^{10}$

Miilujen kolmen päätyypin alle voi lukea useampia alatyyppejä, joiden pystytys- ja polttoprosessit poikkeavat jonkin verran toisistaan. Eniten tietoa 1800-luvun lopun ja 1900-luvun alussa laaditussa miilunpolttokirjallisuudessa on erilaisista pystymiilutyypeistä, mutta kuoppamiiluista on sen sijaan vain hyvin vähän, jos ollenkaan, tietoa. ${ }^{11}$ On todennäköistä, ettei useimmissa tapauksissa ole arkeologisin keinoin mahdollista eritellä maan päälle rakennettujen miilujen alatyyppejä, sillä miilun polttaminen ja purkaminen ovat hävittäneet miilukirjallisuudessa mainitut yksityiskohdat. Toisaalta kuoppamiilujen näkymättömyys vanhoissa miilunpoltto-oppaissa kertoo siitä, etteivät käytäntö ja opaskirjoiksi (ainakin kirjoittajien mielestä) aikansa tarpeisiin laaditut esitykset ole täysin yhteneviä. Historiallisesti miilunrakennustaito on todennäköisesti vaihdellut huomattavasti riippuen siitä, mistä perinnelinjasta on kyse. Miilujen valmistamisessa ja polttamisessa on ollut paikallisia ja ajallisia eroja, joita miiluoppaat tai joltakin tietyltä alueelta taltioitu perimätieto eivät välttämättä tuo esille.

Edellä mainittu miilunpohja on miilunpolttoprosesseista muodostuva jäännös, olettaen että poltto on viety loppuun ja hiilet kerätty pois. Lisäksi maastosta voi harvoin löytyä kokonaan tai osin polttamatta jääneitä miiluja. Poltettu miilu on voinut myös syystä tai toisesta jäädä purkamattomana paikalleen. Useimmiten paikalla on kuitenkin vain miilunpohja eli alue, joka on valmisteltu miilua varten ja johon polton jäljiltä on jäänyt paksu kerros hiilimurskaa, hiilenkappaleita, tuhkaa, peitemaa-aineksia ja joskus myös miilun päälle lapioitua sammutushiekkaa.

\section{Miilunpoltto lyhyesti läpikäytynä}

Pyrolyysiin pohjautuva puuhiilentuotanto tapahtui pääpiirteissään samalla tavalla miilutyypistä riippumatta. Ensimmäinen vaihe oli valmistaa miilulle hyvä alusta eli miilunpohja. Miilunpoltto-oppaiden mukaan paras sijainti miilunpohjalle oli keskellä polttopuiden hankinta-aluetta. Miilunpohjaa pyrittiin käyttämään tilaisuuden tarjoutuessa uudestaan, sillä vanha pohja oli uutta parempi. Miilunpohjan tuli olla tiivis, ettei miiluun pääsisi liikaa ilmaa polton aikana. Vanha pohja sisälsi edellisestä poltosta muodostuneen tuhka- ja pikikerroksen, minkä vuoksi se oli uutta tiiviimpi. Pintaturve poistettiin uuden pohjan kohdalta ja pohjaa saatettiin tarvittaessa tiivistää savella. Maa tasattiin tai miilutyypistä riippuen kaivettiin sopivasti viettäväksi ja pohjan ympäriltä poistettiin kaikki helposti syttyvä. Miilun tuli olla tuulelta suojassa ja maaperän sen alla kuiva, mutta lähettyviltä piti löytyä myös vettä sammutustarkoituksiin. Tarvittaessa miilun alle suositeltiin salaojitusta. Juuria tai isoja kiviä miilunpohjaan ei oppaiden kirjoittajien mukaan sopinut myöskään jättää. ${ }^{12}$

\footnotetext{
${ }^{10}$ Bergström \& Wesslén 1915, 92-107; FAO 1983, 31-35; Hennius 2019, 12, 15; Hirsch et al. 2020, 976-979.

${ }^{11}$ Esim. Bergroth 1885.

${ }^{12}$ Bergroth 1885, 12-14; Lassila 1914, 12-14; Talvitie 1924, 228-230.
} 
Toisaalta Saksan Brandenburgissa tutkittujen pystymiilunpohjien tapauksessa miilunpolttajat eivät vaivautuneet poistamaan juuria. Kotkan Mussalossa suoritettujen kaivausten perusteella ainakin yksi alueen lamamiiluista oli rakennettu suoraan pintaturpeen päälle. Tämä havainnollistaa, miten miilunpolttajien kriteerit miilunpohjan vaatimalle työmäärälle ovat vaihdelleet. En ole tietoinen myöskään miilunpohjien arkeologisissa kaivauksissa ilmi tulleista salaojista.

Miilunpohjan valmistuttua miilunpolttajat asettelivat polttopuut paikoilleen. Puut aseteltiin mahdollisimman tiiviisti vierekkäin ja lopuksi muodostunut miilu peitettiin paksulla kerroksella esimerkiksi kuusenhavuja, risuja, sammalta tai turvetta, jonka päälle lapioitiin maata peitteeksi. Maa-aineksena suosittiin multaa, savensekaista hiekkaa ja edellisten miilujen hiilimurskansekaista peitemaata. Muodostunut peitemaakerros pyrittiin junttaamaan mahdollisimman tiiviiksi etenkin miilun sivuilta. ${ }^{13}$

Miilun varsinainen polttaminen aloitettiin mieluiten tyynellä säällä ja polton edistymistä seurattiin miilusta poistuvan savun väristä. Palovaiheen voi jakaa edelleen kolmeen vaiheeseen. Ensimmäisessä miilupuista poistui kosteutta paksuna valkoisena savuna. Toisessa pyrolyysi eteni miilun sisällä muodostaen palotuotteita, kuten hiiltä, tervaa ja tuhkaa. Kolmannessa miilun loputkin ilmanvaihtoaukot suljettiin ja sen annettiin jäähtyä. Miilun lämpötila vaihteli polton aikana noin 110-600 Celsius-asteen välillä. ${ }^{14}$

Palamisaika riippui muun muassa miilun koosta, puiden paksuudesta, kosteuspitoisuudesta ja siitä, miten paljon happea miiluun pääsi palamisen aikana. Esimerkiksi noin 200 kuutiometriä puuta sisältäneen miilun polttamisen on arvioitu vieneen kymmenen päivää. Polttamisen aikana suurin riski miilulle oli tulen riistäytyminen polttajien hallinnasta ja puiden palaminen tuhkaksi - unohtamatta siitä seurannutta metsäpalon mahdollisuutta. Näin saattoi käydä, mikäli miiluun pääsi liikaa ilmaa joko ilmareikien tai peitteeseen ilmenneiden halkeamien kautta. Halkeamien varalta peitemaata on nuijittu tiiviimmäksi polton edistyessä. ${ }^{15}$

Kun valtaosa miilun polttopuista oli hiiltynyt, seurasi miilun jäähdyttäminen. Miilun annettiin jäähtyä kunnes sen sisäinen lämpötila oli riittävän alhainen, eivätkä hiilet enää syttyneet välittömästi tuleen päästessään reagoimaan hapen kanssa. Jäähdyttämistä joudutettiin vedellä valelemalla. Lisäksi miilun peitemaakerros voitiin vaihtaa uuteen, kasteltuun peitemultaan tai muutaman sentin paksuiseen hiekkakerrokseen, jota kasteltiin lisää sitä mukaa, kun hiekka kuivui. Jäähdyttäminen saattoi suuren miilun tapauksessa kestää viikon tai pidempäänkin. ${ }^{16}$

Lopuksi jäähtynyt miilu purettiin (Kuva 2). Purkaminen suoritettiin joko heti lämpötilan laskettua riittävästi tai myöhemmin, esimerkiksi talvella parempien kuljetusolosuhteiden vallitessa. Miilua purettaessa sen hiilet on nostettu yleensä päältä käsin erityisellä hiili- eli miilukoukulla. Miilun jäähdyttämiseen käytettyä peitekerrosta ei välttämättä poistettu ensin hiilten päältä, jolloin se varisi alempien hiilten sekaan vähentäen vaaraa niiden syttymisestä itsekseen. Miilusta nostetut hiilet joko haravoitiin tai kannettiin hiilikopassa miilun ympärille pitkänomaisiksi kasoiksi eli karhoiksi. Mikäli hiilet karholla ollessaan vielä uhkasivat syttyä tuleen, niitä kasteltiin vedellä. Kylmettyään hiilet lastattiin joko kuljetuslaatikoihin tai varastoitiin viereiseen kevytrakenteiseen hiilivajaan odottamaan myöhempää kuljetusta. ${ }^{17}$

\footnotetext{
13 Bergroth 1885, 14, 15; Lassila 1914, 27-30; Talvitie 1924, 244-247.

${ }^{14}$ Bergroth 1885, 19; Emrich 1985, 29; Powell, Wheeler \& Batt 2012, 1197.

${ }^{15}$ Bergroth 1885, 19-21; Talvitie 1924, 273; Emrich 1985, 32.

${ }^{16}$ Bergroth 1885, 25, 26; Lassila 1914, 41; Helander 1922, 518; Talvitie 1924, 271, 272.

${ }^{17}$ Bergroth 1885, 25, 26; Lassila 1914, 41, 42; Bergström \& Wesslén 1915, 142-145; Seppänen 1939, $20-23$.
} 


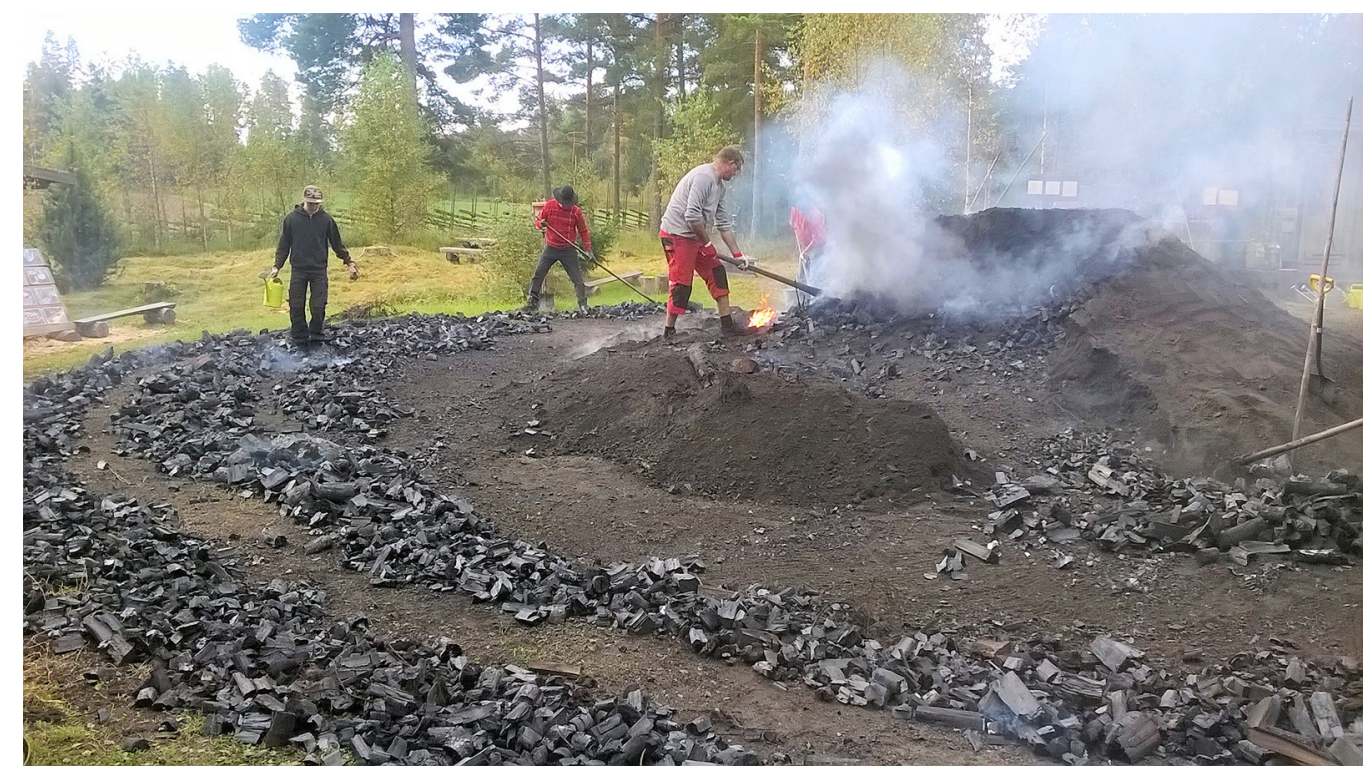

Kuva 2. Pystymiilua puretaan Raaseporin Malmbackassa vuonna 2016. Karhoihin nostettuja hiiliä jäähdytetään tarvittaessa kastelemalla. Kuva: Janne Kangaskesti.

\section{Miilujen kolme päätyyppiä}

Edellä esitetty kuvailee yleisluonteisesti kaikkien suurten miilujen polttoa. Päätyyppien, eli pysty-, lama- ja kuoppamiilujen, välillä on myös eroja. Käyn seuraavaksi läpi kullekin tyypille ominaisia piirteitä aloittaen yleisimmistä eli pystymiiluista.

Pystymiilut ovat historiallisesta ja arkeologisesta aineistosta muodostuvan kokonaisvaikutelman perusteella yleisin miilutyyppi. 1800-luvun lopun ja 1900-luvun alun miilunpoltto-oppaissa pystymiiluilla on keskeinen asema. Tarkemmin pystymiiluja on luokiteltu riippuen siitä, onko miilunpohja tasainen vai kalteva, sekä sytytysmetodin perusteella. Sen sijaan, että pystymiilun polttopuut olisi kasattu suoraan maanpinnalle, ne on saatettu 1800-luvulla tai myöhemmin asetella puista rakennetulle kohotetulle tasolle, eli niin sanotulle sillalle, miilun ilmanvaihdon tehostamiseksi. ${ }^{18}$

Miilupuut pystymiilussa aseteltiin tiiviisti pohjan keskelle pystytettyä napatukkia vasten noin $60^{\circ}$ kulmaan. Miilupuita peitettäessä miilun juurelle jätettiin peitteeseen ilmanvaihtoaukkoja eli jalkaluukkuja, joiden avulla hapensaantia oli mahdollista säädellä polton aikana. Rakenteeltaan yksinkertaisemmassa miilussa, tai kun jalkaluukut eivät riittäneet, sopiva hapensaanti voitiin järjestää hakkaamalla peitekerrokseen polton aikana pieniä reikiä. Pystymiilun sytytys tapahtui joko keskeltä, napatukin vierelle jätetystä aukosta eli palotorvesta tai miilun sivuun muodostetusta onkalosta eli sytytysjuotista. ${ }^{19}$

\footnotetext{
${ }^{18}$ Bergström \& Wesslén 1915, 73, 98-113; Talvitie 1924, 232; Seppänen 1939, 7, 8; Hennius et al. 2005, 106-108; Hennius 2019, 15.

${ }^{19}$ Bergström \& Wesslén 1915, 98-113; Talvitie 1924, 232-239, 249-265.
} 


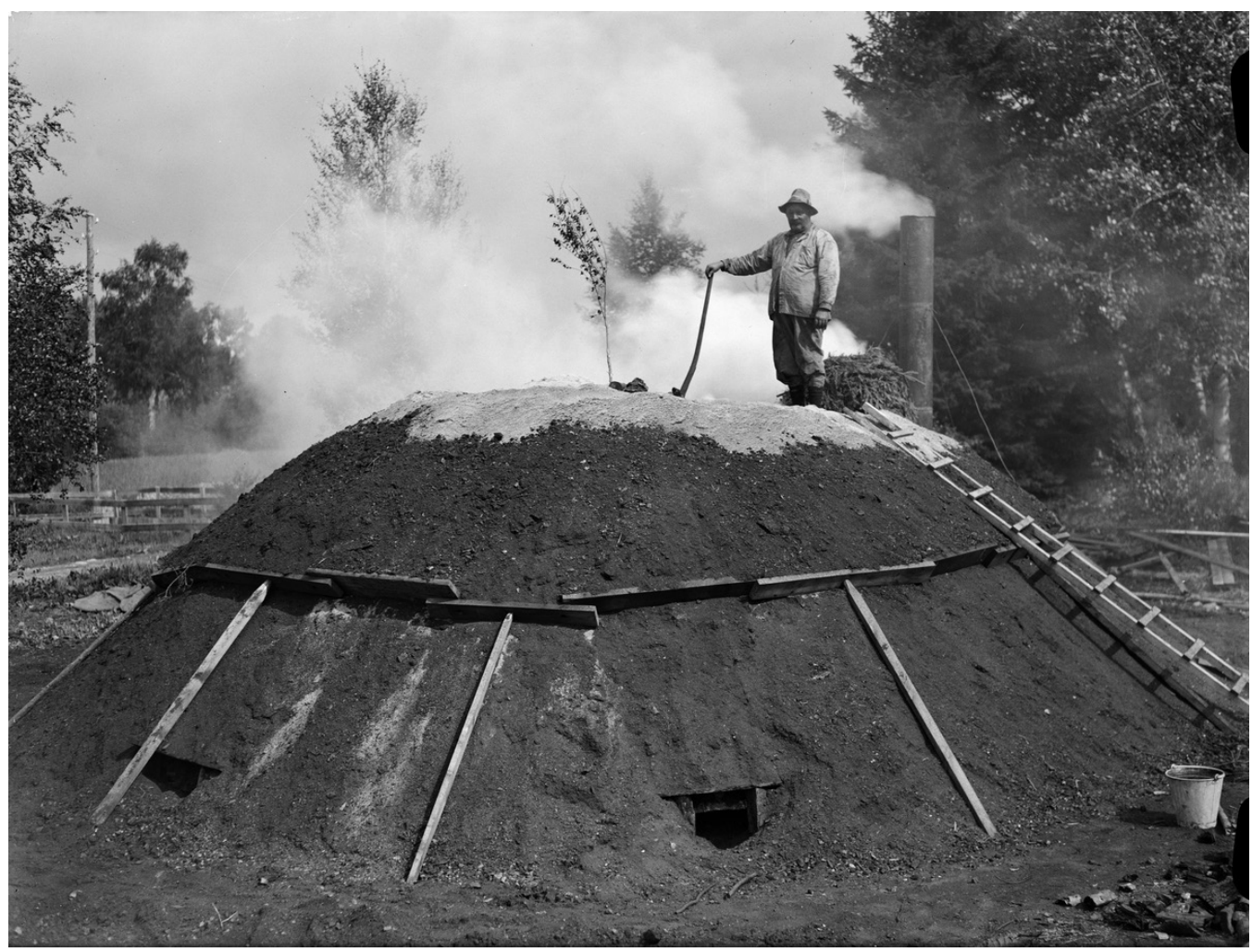

Kuva 3. Torvimiilu Ruotsissa vuonna 1940. Miilun juuressa erottuu kaksi ilmanvaihtoaukkoa eli jalkaluukkua. Kuva: Sandberg, Paul / Upplandsmuseet (CC BY-NC-ND)

Pystymiiluihin lukeutuu myös todennäköisesti viimeinen Suomessa käyttöön omaksuttu miilutyyppi. Vuonna 1933 Ruotsissa kehitetty torvimiilu (Kuva 3) on erotettavissa muista miilutyypeistä paitsi lyhyen käytössäoloaikansa, myös miilunpohjan erityispiirteiden osalta. Torvimiilut ohjeistettiin rakennettaviksi sillan varaan ja miilun juurelle tehtiin noin metrin verran siitä ulkoneva savukanava. Kanava voi olla joko kaivettu maahan tai kasattu kivistä maanpinnalle. Sen päähän koottiin kivistä tulisija. Miilutyyppi on saanut nimensä tulisijan päälle polton ajaksi asetetusta piipusta eli savutorvesta. Rakenteen tarkoitus oli parantaa miilun ilmanvaihtoa polton aikana. ${ }^{20}$

Lamamiilut ovat tämänhetkisen vaikutelmani perusteella Suomessa selvästi harvinaisempi miilutyyppi. Tavallisessa lamamiilussa tasamittaiset polttopuut ladotaan tiiviisti vaakasuoraan telapuiden päälle ja tuetaan sivuilta maahan isketyillä pystypaaluilla. Miilunpohja oli muodoltaan suorakaide ja voi olla joko tasainen tai kalteva. Museoviraston Historiallisen ajan kïnteät muinaisjäännökeset -oppaassa mainitaan, että lamamiilun polttopuita varten olisi

${ }^{20}$ Seppänen 1939, 3, 7-16. 


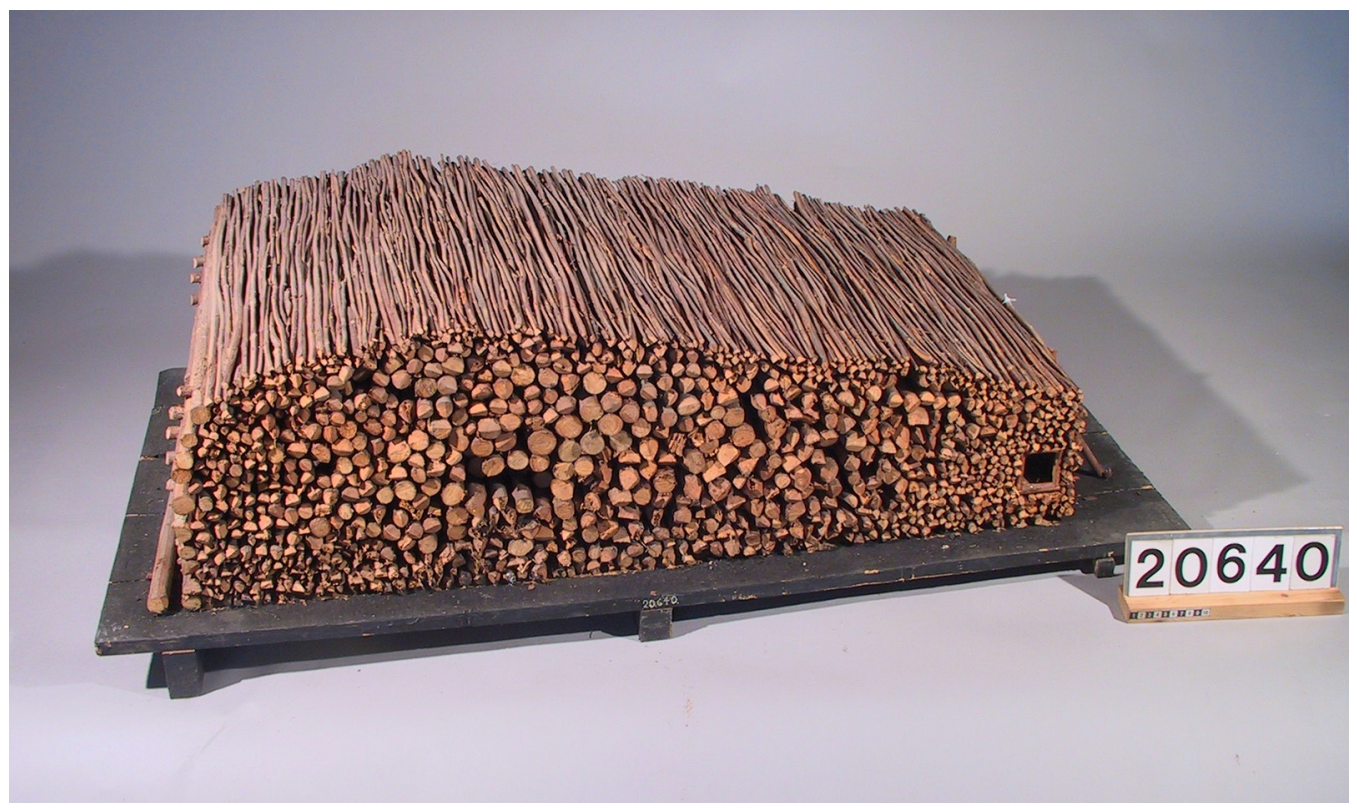

Kuva 4. Pienoismalli lamamiilun puiden asettelusta. Sytytysjuotti on oikeassa päädyssä. Kuva: Tekniska Museet (CC BY)

kaivettu kuoppa. ${ }^{21}$ Kyseessä on kuitenkin sekaannus lama- ja kuoppamiilujen välillä. Miilunpoltto-oppaissa kuvaillut lamamiilut pystytettiin maanpinnalle. Ruotsalaisessa arkeologisessa tutkimuksessa tarkastellut lamamiilunpohjat ovat samoin maanpinnalle rakennettuja. ${ }^{22}$ Toisesta päädystään lamamiilu saattoi koostua pienemmästä puusta ja olla matalampi (Kuva 4). Tähän päätyyn on sijoitettu sytytysjuotti. Tavallisen lamamiilun peittäminen oli haastavaa pystysuorien pitkien sivujen vuoksi. Niille rakennettiin yleensä pystypaalujen varaan tuettu seinärakenne peitteen paikoillaan pitämiseksi. ${ }^{23}$

Pystysuorien seinärakenteiden asettama haaste johti toisenlaisten lamamiilumallien kehittämiseen. Yksi näistä oli Österby-miilu, jonka pitkät sivuseinät olivat kaltevat, sillä polttopuita ladottaessa ylempiin kerroksiin aseteltiin edellistä lyhyempiä puita. Miilu kapeni ylhäältä keskikohtaa kohti. Lisäksi miilun pohja ei ollut täysin suorakaiteen muotoinen, vaan sen pitkien sivujen puoliväliin oli asetettu kerroksen pisimmät puut. Rakennelman peittäminen oli täten tavallista lamamiilua helpompaa, sillä erillisiä tukiseiniä ei tarvittu. ${ }^{24}$

Kuoppamiilut, joista käytetään myös nimityksiä hiili- tai sysihauta, erosivat edellä mainituista päätyypeistä ensisijaisesti siltä osin, että polttopuu aseteltiin niissä maahan kaivet-

\footnotetext{
${ }^{21}$ Niukkanen 2009, 41, 42.

${ }^{22}$ Esim. Wennerberg 2008.

${ }^{23}$ Lassila 1914, 23-30.

${ }^{24}$ Talvitie 1924, 241-243, 246.
} 
Kuva 5. Suuren kuoppamiilun rakenne. Ilmanvaihtohormien määrä ja sijainti ovat viitteellisiä. Kuva: Janne Kangaskesti.

tuun kuoppaan. ${ }^{25}$ Tämä päätyyppi on miilujen luokittelussa kuitenkin vakiintumattomampi kuin edellä käsitellyt ja käsittää kooltaan ja rakenteeltaan erilaisia miiluja, joiden jäännökset ovat huonosti tunnettuja. On perustellusti mahdollista esittää vaihtoehtoisia miilujäännösten luokitteluja, mihin palaan edempänä. Kuop-
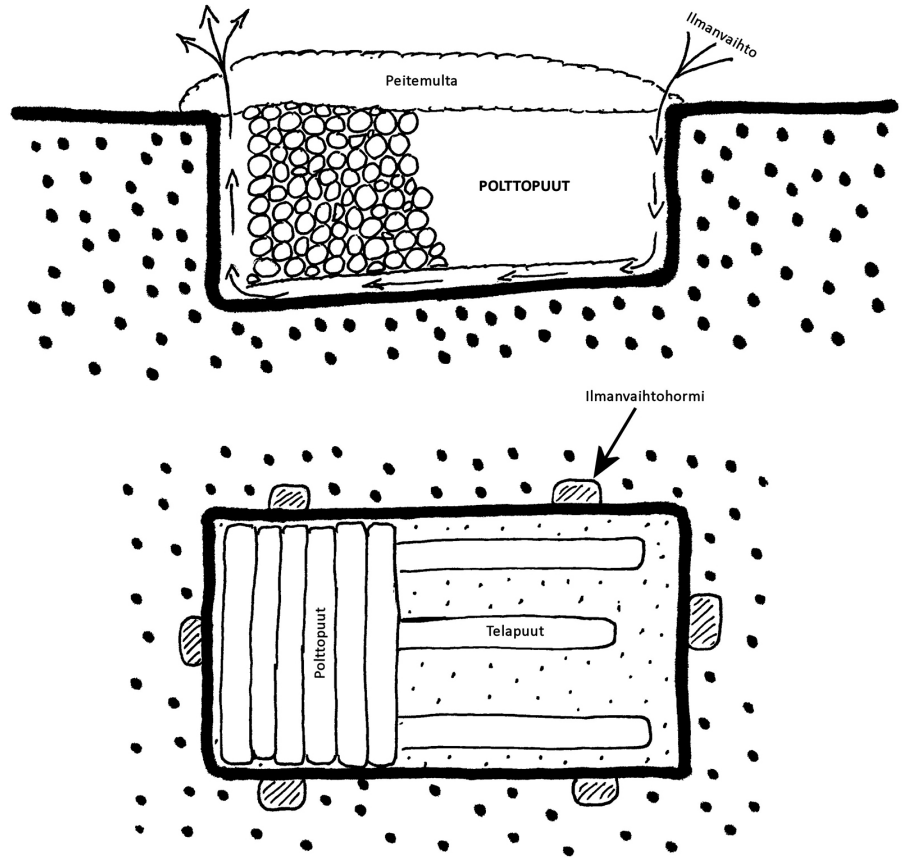
pamiilujen päätyypin voi jakaa Suomen kontekstissa suuriin, rakenteeltaan tavallista lamamiilua muistuttaviin kuoppamiiluihin, joita olen kutsunut pro gradussani tavallisiksi kuoppamiiluiksi sekä pieniin, usein yksinkertaisiin kuoppamiiluihin, joita saatetaan kutsua myös hiilikuopiksi.

Kaikki kuoppamiilut rakennettiin mieluiten hiekka- tai hietamaahan, joka ei saanut varista liiaksi. Tämä oli tärkeää erityisesti suurten (tavallisten) kuoppamiilujen tapauksessa, sillä muuten ilmanottoaukot olivat vaarassa tukkeutua kesken polton. Suuren, esimerkiksi noin 9 kertaa 15 metrin kokoisen kuoppamiilun pohjaksi kaivettiin suorakaiteen muotoinen 2 metriä syvä kuoppa, jonka pohja voi viettää hieman toiseen päätyyn (Kuva 5). Kuopan pohjalle aseteltiin ilmanvaihdon varmistamiseksi telapuut tai pienemmistä puista silta, jonka päälle puut ladottiin vaakatasoon kuten lamamiilussa. Lisäksi kuopan laidoille puiden viereen kaivettiin savuhormit, joiden määrä vaihteli. Polton ja purkamisen jälkeen hormien paikat erottuvat miilunpohjassa kuoppaa reunustavassa vallissa matalina painanteina. ${ }^{26}$

Tämänhetkisten havaintojen osalta ainakin Pohjois-Savossa ja Pohjois-Karjalassa esiintyvien suurten (tavallisten) kuoppamiilunpohjien rakennetta ei ole arkeologisesti tutkittu, eikä miilunpohjien mittasuhteita ole kartoitettu systemaattisesti. Edellä esitetyt luvut ovat siten omia karkeita arvioitani. En ole tähän mennessä myöskään löytänyt vastaavia kohteita ulkomaisista kaivausraporteista, mutta 1900-luvun jälkipuoliskolla laadituissa hiilenpolttooppaissa vastaavia miiluja on kuvailtu. ${ }^{27}$ Miilutyyppi on mahdollisesti yhä käytössä Afrikassa ja Aasiassa.

\footnotetext{
${ }^{25}$ Esim. Bergroth 1885, 7; FAO 1983.

${ }^{26}$ Emrich 1985, 24-27; Mönkkönen 2012, 44, 45.

${ }^{27}$ Esim. FAO 1983.
} 
Pienikokoiset kuoppamiilut ovat piirteiltään vaihteleva ryhmä. Siinä erottuu alatyyppeinä ainakin suorakulmainen, verrattain matalaan painanteeseen rakennettu miilu sekä syvempään, neliskanttiseen tai mahdollisesti pyöreään kuoppaan koottu miilu. Esimerkkinä ensiksi mainitusta Ruotsin Itä-Götanmaalla kaivettu keskiaikainen miilunpohja oli kooltaan noin 4,5 kertaa 4 metriä ja noin 0,35 metriä syvä. ${ }^{28}$ Alankomaissa dokumentoitujen suorakaiteen muotoisten kuoppamiilunpohjien sivun pituus vaihtelee yleensä 0,8-2,5 metrin välillä ja syvyys jää alle 0,4 metriin, joskin se on alkujaan voinut olla noin metrin. ${ }^{29}$ Tällaiset miilut ovat paikoin yhä käytössä muun muassa Länsi-Afrikassa. ${ }^{30}$ Gradussani laskin nämä miilut samaan ryhmään suurten (tavallisten) kuoppamiilujen kanssa, mutta olen sittemmin alkanut epäillä, onko niiden jäljiltä tunnettujen miilunpohjien luokittelu samaan ryhmään käytännöllistä saatavilla olevien tietojen pohjalta. Avoin kysymys on, miten erilaisten pienten kuoppamiilujen ilmanvaihto on järjestetty.

Esimerkkinä syvempään kuoppaan kaivetusta pienikokoisesta kuoppamiilusta Hauhossa hiiliä on muistitietojen mukaan hankittu kotitarpeisiin hiilikuopassa, joka on ollut noin 1,8 kertaa 1,5 metriä ja syvyydeltään 1,5 metriä. ${ }^{31}$ Kyseinen kuoppamiilu on, mikäli muistitietoon on luottaminen, ollut erittäin yksinkertainen. Se on peitetty vasta kun kaikki kuoppaan asetettu puu oli palanut jo hyvän aikaa, eikä peitteeseen ole jätetty enää tässä vaiheessa ilmanottoaukkoja.

Miilunpoltosta maastoon jääneiden miilunpohjien levintää ei ole kartoitettu Suomessa. Miilunpohjien huomioiminen arkeologisissa inventoinneissa on ollut aikojen saatossa vaihtelevaa, eikä kohteiden dokumentoinnin osalta ole ollut yhteneviä käytäntöjä. Tilanne on ollut samankaltainen Ruotsissa, mutta siihen on kiinnitetty viime vuosina huomiota. ${ }^{32}$

\section{Kaksi esimerkkiä miilukonteksteista Suomessa: Teijo}

Pitkän yhteisen historian vuoksi miilunpolton arkeologinen aineisto on Suomessa ja Ruotsissa pääosin samankaltaista. Esimerkkinä tästä Varsinais-Suomessa Salon Teijon 1600-luvun lopussa perustetun ruukin (privilegio masuunille myönnettiin vuonna 1686) ympäristöstä löytyy runsaasti miilunpohjia ja miilumajojen jäännöksiä, joille on runsaasti vastineita Ruotsissa. Ruukkien hiilenhankinta-alueilla on suosittu ennen muuta pystymiiluja, kunnes miiluuunit ja myöhemmin kivihiili yleistyivät 1800-luvun puolivälistä alkaen. ${ }^{33}$

Hiilimiiluja poltettiin Teijon ruukin ympäristössä noin 200 vuoden ajan aina 1870-luvulle asti. ${ }^{34}$ Ruukin valtavan hiilentarpeen tyydyttäminen on vaatinut läheisten kangasmetsien intensiivistä hyödyntämistä miilunpoltossa. Ruukin lähimetsien alueelta onkin laserkeilausaineistosta paikannettavissa ainakin 370 mahdollista miilukohdetta (Kuva 6). Useimmat niistä sijoittuvat teiden varrelle tai läheisyyteen, mikä on helpottanut hiilten kuljetusta ruukille. Havaitut miilunpohjat ovat muodoltaan pyöreitä, matalia kumpuja, eli ne ovat pystymiilun

\footnotetext{
${ }^{28}$ Rolöf \& Österström 2007, 9.

${ }^{29}$ Groenewoudt 2007, 328, 329; Hirsch et al. 2020, 976, 977.

${ }^{30}$ Vilppo et al. 2016, 67, 68.

${ }^{31}$ Vanhaa Hauhoa 1934, 238.

${ }^{32}$ Hennius 2019, 19-25.

${ }^{33}$ Ekman 1937; Laine 1948, 259; Hennius et al. 2005, 108, 109; Taivainen 2010; Kangaskesti 2019, 46, 84-88.

${ }^{34}$ Ekman 1937, 72, 73, 273.
} 


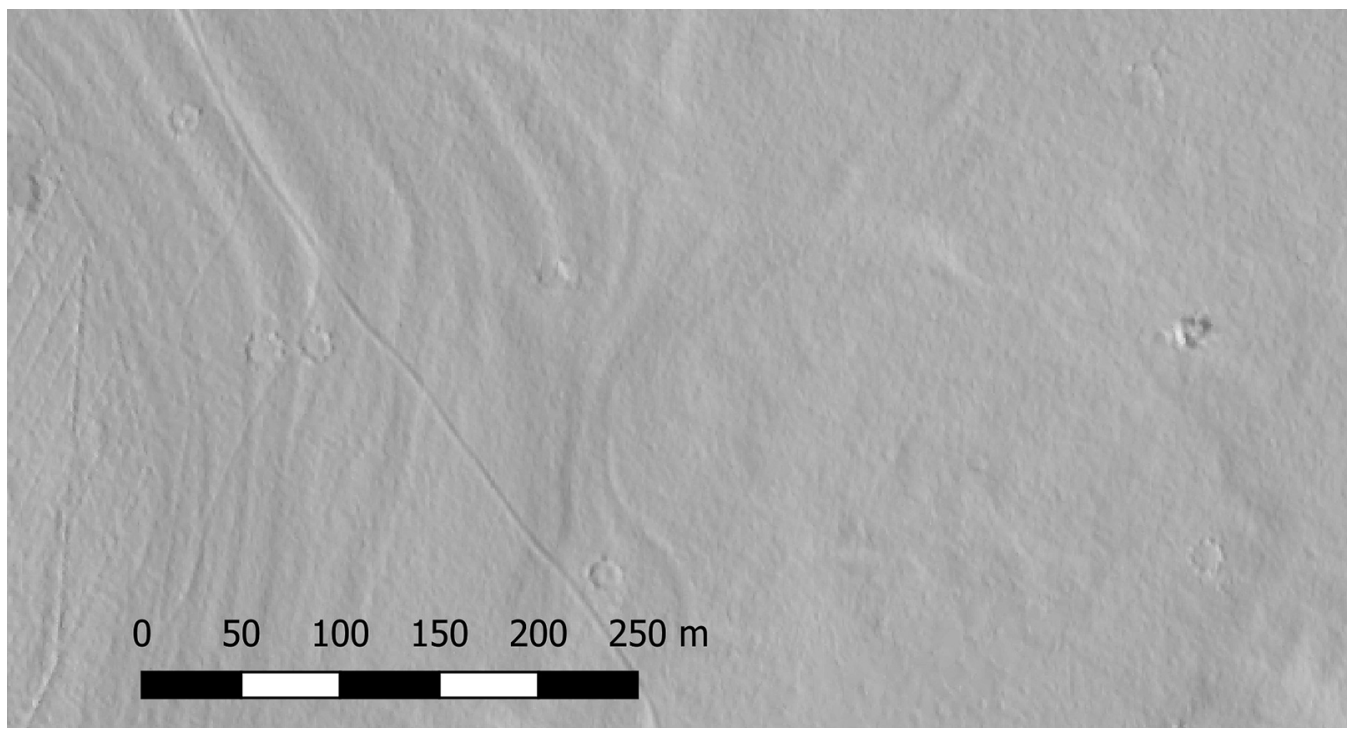

Kuva 6. Kuoppien ympäröimiä pystymiilunpohjia Lidar-kuvassa Salon Teijon Yrjännummella. Kuva: Maanmittauslaitos Laserkeilausaineisto (CC 4.0).

jäljiltä, ja niiden halkaisija on sekä laserkeilausaineistosta arvioiden että nykyisen kansallispuiston aluetta inventoineen Jouni Taivaisen mittausten perusteella pääasiassa 12-16 metriä. Osa yltää noin 20 metrin halkaisijaan. Kummun korkeus on useimmiten 0,5-1,0 metriä. Yhteistä valtaosalle alueen miilunpohjista ovat pohjaa ympäröivät suuret kuopat ja ojanteet. Kuoppia on yleensä 4-6 ja ne ovat useimmiten noin metri kertaa 2 metriä kooltaan ja 0,5-1 metriä syvyydeltään. Ojanteet ovat harvinaisempia, mutta vastaavan syvyisiä ja noin metrin leveitä. Ne voivat kiertää miilunpohjaa pareittain, reunustaa sitä parin kuopan kanssa, tai joissain tapauksissa kiertää koko miilunpohjan ympäri. ${ }^{35}$

Ruukin lähellä sen omistamiin metsiin sijoittuvia miilunpohjia on todennäköisesti käytetty useampaan otteeseen. Teijon tapauksessa tunnetuista kohteista ei kuitenkaan ole kaivauksia tai koekairauksia, jotta asian voisi varmistaa maaperän stratigrafiasta. Mahdollisesti kuoppien ja ojanteiden määrä ja syvyys on uusiokäytön seurasta, mikäli niistä on kaivettu toistuvasti sammutushiekkaa miilun päälle. Vaihtoehtoinen selitys kuopille on maaperän kuivattaminen. Ojanteet on toisinaan yhdistetty miilujen polttamiseen kesällä, jolloin miilua ympäröivä oja ehkäisisi maastopaloja. Miilun ilmanvaihtoaukkoihin eli jalkaluukkuihin ympäröivät kuopat tuskin kytkeytyvät, koska viitteitä pohjan laidalta kuoppiin johtavista hormeista ei ole havaittu. Lisäksi miilua ympäröivän ojanteen tapauksessa kaivauksissa on havaittu, että ojanteen ja varsinaisen miilun välillä on ollut noin metri tilaa. Sama voi päteä kuoppiin. ${ }^{36}$

Vallin ympäröimiä miilunpohjia Teijon alueelta ei ole löytynyt. Mielenkiintoisesti PerOlof Fredman on tarkastellut vallillisia miilunpohjia Uppsalan läänissä ja esittänyt, että

\footnotetext{
35 Taivainen 2010.

${ }^{36}$ Fredman 2009, 10-13; Hennius et al. 2005, 101-108; Wennerberg 2008, 21, 29-33; Hirsch et al. 2020, $977,978$.
} 
ne liittyvät miilun polttamiseen korotetun tason eli sillan päällä ja ajoittuvat ajanjaksolle 1870-1925. ${ }^{37}$ Täten käytäntö olisi ainakin kyseisellä alueella alkanut samoihin aikoihin kun miilunpoltto Teijossa loppui.

Usean miilunpohjan yhteydessä on todennäköinen miilumajan jäännös. Kyseessä on useimmiten U:n muotoinen, noin 2-4 kertaa 3-6 metriä ja alle puoli metriä korkea maavalli. Valli on jäännös majan maaseinärakenteista. Sen kaarteessa on kylmämuurattu liesirakenne, joka on kooltaan noin 1,5 kertaa 1,5 metriä. Lieden suuaukon päällä on yleensä suuri laakakivi. Vallin ulkoreunalla voi olla havaittavissa matala ojanne, joka on mahdollisesti syntynyt seinien rakentamisen yhteydessä. Joissakin tapauksissa näitä liesirakenteita on nimitetty ryssänuuneiksi, mutta kyse on todennäköisesti rakenteen alkuperän myöhemmästä virhetulkinnasta. Vastaavia liesirakenteita on löydetty runsaasti Ruotsista hiilenpolttokonteksteista. ${ }^{38}$

Teijon alueella laserkeilausaineistosta paikannetut mahdolliset ja inventoinnissa varmistetut miilunpohjat ovat, kuten mainittua, kaikki pystymiilujen jäljiltä. Myös lamamiiluja on saatettu polttaa Teijossa, mutta niiden paikantaminen voi olla pystymiilunpohjia vaikeampaa. Mahdollisesti miilunpohjien vallittomuus viittaa siihen, että miilut rakennettiin suoraan maan pinnalle, mutta asian varmistaminen vaatii kohteiden tutkimista. Toisaalta torvimiiluja Teijossa ei ole koskaan käytetty, sillä kyseinen pystymiilutyyppi kehitettiin vasta kun miilunpoltto ruukille oli jo loppunut.

\section{Kaksi esimerkkiä miilukonteksteista Suomessa: Rautavaara}

Pohjois-Savon Rautavaaran alueelta on historiallisissa lähteissä mainintoja raudanvalmistuksesta ainakin 1680-luvulta alkaen. ${ }^{39}$ Ruukkitoiminnan sijaan kyseessä on ollut talonpoikien harjoittamaa kotiteollisuutta. Toiminta on jatkunut paikallisen perimätiedon mukaan ainakin 1800-luvun ensimmäisille vuosikymmenille. ${ }^{40}$ Myöhemmin paikallinen raudanvalmistus on hiipunut, mutta alueen järvistä ja soista on nostettu rautamalmia lähistölle perustettujen ruukkien tarpeisiin. ${ }^{41}$ Talonpoikien käyttämien harkkohyttien yhteyteen on tehty myös miiluja, jotka ruukkikontekstista poiketen ovat olleet suuria kuoppamiiluja.

J. Lukkarinen luetteloi Rautavaaran alueelta yhteensä 89 historiallista raudanvalmistuskohdetta. ${ }^{42} \mathrm{Ne}$ käsittävät kukin ainakin yhden harkkohytin, eivätkä tiettävästi liity ruukkien toimintaan - joskin tätä mahdollisuutta ei voi sulkea pois ainakaan Tiilikka-järven tapauksessa. ${ }^{43}$ Osan kohteista Lukkarinen paikansi maastossa, mutta useimmat pohjautuvat pelkästään paikallisilta kerättyyn muistitietoon. Joidenkin kohteiden tiedettiin tuhoutuneen jo ennen vuotta 1939. Osa on vuorostaan joko kuvailtu liian niukasti paikannettavaksi tai on muuten epävarmoja tapauksia. Jäljelle jää kuitenkin 36 kohdetta, joista osa on sittemmin paikannettu inventoinneissa ja merkitty muinaisjäännösrekisteriin tai on havaittavissa laserkeilausaineistosta. Jokaisen kohteen yhteydessä on suurikokoinen kuoppamiilunpohja, joka

\footnotetext{
${ }^{37}$ Fredman 2009, 10, 11.

${ }^{38}$ Hennius et al. 2005, 108, 109; Taivainen 2010, 29-41, 67, 79-86, 91-93, 120, 121.

${ }^{39}$ Saloheimo 1953, 67.

40 Lukkarinen 1939, 18, 19.

${ }^{41}$ Roininen 1978.

42 Lukkarinen 1939; Kangaskesti 2019, 89-95.

${ }^{43}$ Roininen 1978, 20.
} 


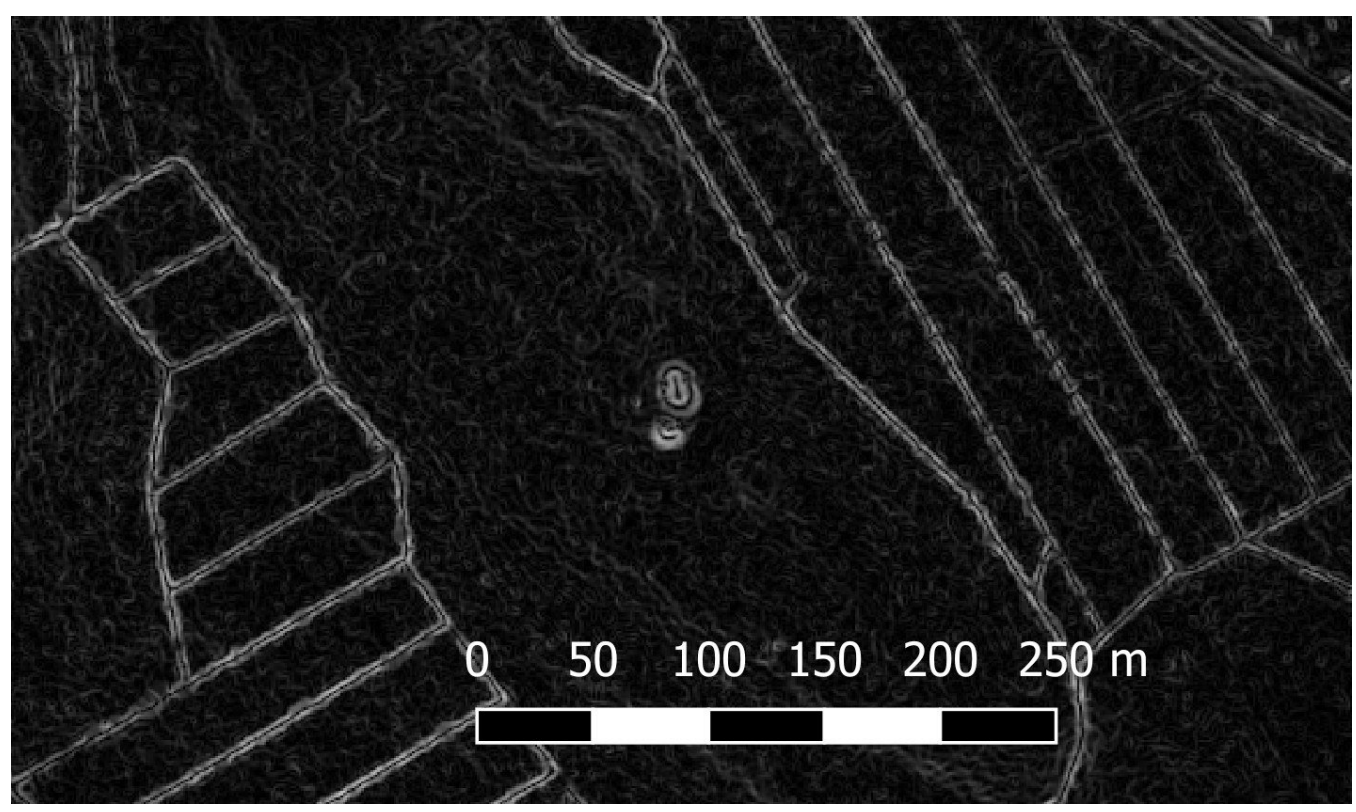

Kuva 7. Rautavaaran Kuistinsuon Koukkelon raudanvalmistuspaikka kaltevuuskorostetussa Lidarkuvassa. Kohde käsittää suuren kuoppamiilunpohjan, jonka vieressä on harkkohytti ja kaareva kuonakasa. Kuva: Maanmittauslaitos Laserkeilausaineisto (CC 4.0).

erottuu laserkeilausaineistossa selkeästi (Kuva 7). Lisäksi olen paikantanut 22 miilunpohjallista raudanvalmistuspaikkaa, joita ei voi varmuudella yhdistää Lukkarisen luettelemiin kohteisiin. $^{44}$

Esimerkkinä kuoppamiilunpohjista Ylä-Luostan länsirannalla sijaitsevan Aarrekankaan raudanvalmistuspaikan miilunpohja on 11 metriä kertaa 8 metriä sivuiltaan ja 1,5 metriä syvyydeltään. Sen välittömässä läheisyydessä on havaittavissa hajotetun harkkohytin toiselta puolelta kuonaantuneita kiviä, suuri sulatuskuonakasa ja kolikkomaisia järvimalmin kappaleita paikalta, johon malmi on kerätty kasaksi. Kohde on mittasuhteiltaan melko tyypillinen alueelle, mutta miilunpohjissa esiintyy runsaasti pientä kokovaihtelua. Myös kohteen sijainti kangasmetsäisen hiekkamoreenirinteen harjanteella, malmirikkaan vesistön lähellä, on sekin tyypillinen. Useimmiten miilunpohjia on vain yksi per valmistuspaikka.

Aarrekankaan miilunpohjaa ympäröi matala valli ja sekä pohjan keskiosassa että vallissa on runsaasti hiiltä. Kuopan pohja on tiivis, mihin viittaa suureksi lätäköksi jäävä sadevesi. Ympäröivä hiekkamoreeni suodattaa hyvin vettä. Miilunpohjan pitkillä sivuilla on kummallakin puolella vallissa painanne, jonka halkaisija on noin metrin ja syvyys 0,3 metriä. Vastaavia painanteita on muidenkin tarkastamieni suurten kuoppamiilunpohjien valleissa. Niiden määrä vaihtelee jonkin verran, mutta useimmiten niitä on kaksi per pitkä sivu. Lisäksi Aarrekankaan miilunpohjan lounaispäädyssä on pohjan keskustasta ulospäin suuntautuva ojanne, joka halkaisee vallin ja on noin 2-3 metriä pitkä ja 0,2 metriä syvä. Vastaava ojanne puuttuu muista tarkastamistani kuoppamiilunpohjista. Oletettavasti nämä rakenteet liittyvät miilun ilmanvaihtoon, kuten Lukkarisen haastattelema paikallinen seppä hänelle totesi. ${ }^{45}$

\footnotetext{
${ }^{44}$ Kangaskesti 2019, 96, 97.

45 Lukkarinen 1939, 20.
} 
Rautavaaralla on myös myöhempi miilunpolton vaiheensa. Toisen maailmansodan aikana alueella poltettiin hiiltä sinne rakennetun lentokentän tarpeisiin ja luultavasti myös muualle vietäväksi. Vuonna 1941 otetuista ilmakuvista on mahdollista paikantaa useita hiilenpolttopaikkoja miiluineen, polttopuukasoineen ja hiilivajoineen eri puolilta kunnan aluetta. ${ }^{46}$ Tähän toimintaan liittyvät miilunpohjat eroavat selvästi aiemmista kuoppamiilunpohjista, sillä kyse on pystymiilunpohjista. Osa näistä pohjista eroaa Teijon ruukin miilunpohjista vuorostaan siten, että niitä ympäröi rengasvalli ja ne ovat keskeltä tasaisia. Kuoppia ympärillä ei ole ollenkaan. Näin on esimerkiksi Jokilammen hiilenpolttopaikalla. On vaikea sanoa liittyykö rengasvalli miilunpolttotekniikkaan, esimerkiksi niin sanotun sillan käyttöön, vai onko kyse polton jälkeisestä miilunpohjan alustavasta valmistelusta seuraavaa polttoa varten. Toisaalta Hiilimiilukankaan kumpumaisilla miilunpohjilla rengasvallia ei ole, muttei myöskään Teijosta tuttuja kutakin pohjaa ympäröiviä suurehkoja kuoppia. Tämä voi liittyä eroihin miilunpolttotavoissa, mutta myös siihen, että toisin kuin Teijon miilunpohjia Hiilimiilukankaan pohjia ei välttämättä ole käytetty uudestaan.

\section{Miilunpohjien luokittelua}

Edellisistä lyhyistä esimerkeistä käy ilmi, että miilunpohjat eroavat toisistaan myös miilujen päätyyppien sisällä. Tämä voi johtua niin miilun valmistamiseen, polttamiseen kuin erityisesti purkamiseenkin liittyvistä käytäntöeroista. Miilunpolttajien opit ja kokemus sekä hiilenpolttopaikkojen paikalliset piirteet ovat vaikuttaneet suuresti siihen, millaiseksi miilunpohja on toiminnan päätyttyä jäänyt.

Pro gradussani noudatin pääsääntöisesti miilunpoltto-oppaissa ilmenevää kolmijakoa pysty-, lama- ja kuoppamiiluihin miilunpohjineen (Taulukko 1). Tämän lisäksi jaoin kuoppamiilut kahteen ryhmään, joita nimitin tavallisiksi kuoppamiiluiksi ja yksinkertaisiksi kuoppamiiluiksi. Miilunpohjien erottelevat piirteet ryhmittelin pohjan keskiosan ja laidan mukaan. Kuoppamiilujen kaksi alatyyppiä erotin sen mukaan, onko niiden ohessa ilmanvaihtoa. Jako heijastelee jossain määrin myös miilujen kokoa, sillä suuren puumäärän tehokas hiiltäminen vaatii riittävän ilmanvaihdon suunnittelemisen miilun rakenteeseen - ainakin mikäli kuoppa on syvä.

Tällä hetkellä en ole vakuuttunut, että suurempienkaan suorakaiteen muotoisten, noin metrin syvyisten tai matalampien miilunpohjien yhteydessä varsinaisten ilmanvaihtohormien rakentaminen olisi välttämätöntä. Miilu on voitu polttaa esimerkiksi laidalta aloittaen ja peittäen hiiltymässä olevat puut sitä mukaa kun palo etenee. Erittäin yksinkertaisten ilmanvaihtoratkaisujen jaottelu voi ylipäätään olla semanttista. Selkein jako kuoppamiilunpohjissa vaikuttaa olevan miilun volyymin määrittelemä.

Muiden miilunpohjien tarkempi luokittelu jäännöksessä havaittujen piirteiden mukaan on mahdollista. Tästä on esimerkkinä Ruotsista Per-Olof Fredmanin kahdeksan Upplannisssa tavatun miilunpohjatyypin luokittelu. ${ }^{47}$ Tyypit kuvastavat erilaisia pysty- ja lamamiilunpohjia. Ruotsissa on pyritty alustavasti selvittämään eri miilutyyppien levintää, mutta tarkemman yleisjaottelun haasteena on miilunpohjien piirteiden alueellinen vaihtelu ja inventoinnissa todettujen miilunpohjien niukka dokumentointi. ${ }^{48}$

\footnotetext{
46 "Historialliset ilmakuvat", kartta.paikkatietoikkuna.fi 1.6.2021.

${ }^{47}$ Fredman 2009, 10-13; piirros myös Hennius 2019, 26.

${ }^{48}$ Hennius 2019, 23-25.
} 


\begin{tabular}{|l|l|l|}
\hline Miilun tyyppi & Keskiosa & Laita \\
\hline $\begin{array}{l}\text { Pystymiilu } \\
\text { (miilunpohja pyöreä) }\end{array}$ & $\begin{array}{l}\text { Kumpu (usein 0,2-1,0 metriä } \\
\text { korkea) tai tasainen } \\
\text { Kummun keskellä voi olla } \\
\text { pieni painanne (hiilien poista- } \\
\text { misen jäljiltä) }\end{array}$ & $\begin{array}{l}\text { Usein kuoppia, ojanteita } \\
\text { Oja voi kiertää koko miilun } \\
\text { Joskus valli (yleensä keskiosa tuol- } \\
\text { loin tasainen) } \\
\text { Kivinen liesirakenne (torvimiilussa) }\end{array}$ \\
\hline $\begin{array}{l}\text { Lamamiilu } \\
\text { (miilunpohja suora- } \\
\text { kaide) }\end{array}$ & Kumpu tai tasainen & $\begin{array}{l}\text { Kuoppia, ojanteita } \\
\text { Joskus valli }\end{array}$ \\
\hline $\begin{array}{l}\text { Tavallinen kuoppa- } \\
\text { miilu } \\
\text { (miilunpohja suora- } \\
\text { kaide) }\end{array}$ & $\begin{array}{l}\text { Syvä (usein 1,5-3,0 metriä) tai } \\
\text { matala (usein 0,1-1,0 metriä) } \\
\text { painanne miilunpohjan koosta } \\
\text { riippuen }\end{array}$ & $\begin{array}{l}\text { Valli, jossa mahdollisesti painanteita } \\
\text { (mikäli miilunpohja on suuri) }\end{array}$ \\
\hline $\begin{array}{l}\text { Yksinkertainen kuop- } \\
\text { pamiilu eli hiilihauta } \\
\text { (miilunpohja pyöreä } \\
\text { tai suorakaide) }\end{array}$ & $\begin{array}{l}\text { Painanne (usein } 0,1-1,0 \text { met- } \\
\text { riä syvä) }\end{array}$ & Valli \\
\hline
\end{tabular}

Taulukko 1. Pro gradussa hahmottelemani miilujen ja miilunpohjien jako.

Uuden, alueellisesti laajempaan esimerkkiaineistoon pohjautuvan miilunpohjien luokittelun ovat laatineet Florian Hirsch et al. artikkelissaan "An initiative for a morphologicgenetic catalog of relict charcoal hearths from Central Europe" (2020). Artikkeli jakaa miilunpohjat kolmeen tyyppiin (Taulukko 2). Tyyppi 1 kattaa kuoppamiilunpohjat (pit charcoal production), tyyppi 2 käsittää tasamaalle rakennetut miilunpohjat ja tyyppi 3 kaltevalle pinnalle rakennetut miilunpohjat, joihin kirjoittajat lukevat sekä rinteeseen rakennetut pystymiilunpohjat (3b, 3c) että lamamiilunpohjat (3a). Tyypin 2 yhteydessä ei käsitellä lamamiiluja ollenkaan, vaan alatyypit a-c on varattu pyöreän pystymiilunpohjan erilaisille reunailmiöille. Esitetyssä jaossa lamamiilunpohjien luokitus pohjautuu siihen oletukseen, että lamamiilut on rakennettu aina kaltevalle pinnalle. ${ }^{49}$ Miilunpoltto-oppaissa lamamiilun toinen pää neuvotaankin asettamaan matalammalle ("niin että pohja laskee noin $60 \mathrm{~cm} 10$ pituusmetriä kohti"). ${ }^{50}$

Poltto-oppaissa kuvailtu lamamiilunpohja viettää kuitenkin melko loivasti. Se ei edellytä miilun sijoittamista maastossa rinteeseen, vaikka siitä onkin etua, mikäli rinne ei ole liian jyrkkä. On kyseenalaista erottuuko pohjan lievä kallistus polton jälkeen miilunpohjasta muuten kuin kohteeseen kajoamalla, mikäli kohde ei selkeästi sijaitse viettävällä maaperällä.

Tasamaan miilunpohjien tyyppi 2 :n alajaossa $2 \mathrm{c}$ on vallin ympäröimä pohja, $2 \mathrm{~b}$ käsittää sekä ojalliset että kuopalliset pohjat ja 2 a kummulliset ilman reunailmiöitä. On hyvin todennäköistä, että ojat ja kuopat ovat muodostuneet samanlaisten toimien seurauksena, minkä vuoksi on perusteltua liittää ne samaan kategoriaan. ${ }^{51}$ Toisaalta on mahdollista, että ero viittaa johonkin vielä tunnistamattomaan funktionaaliseen tai ajalliseen eroon miilun-

\footnotetext{
${ }^{49}$ Hirsch et al. 2020, 976-979.

${ }^{50}$ Lassila 1914, 23.

${ }^{51}$ Hirsch et al. 2020, 975, 977-979.
} 


\begin{tabular}{|c|c|c|c|}
\hline Tyyppi & Piirteet & Maa & Ajoitus \\
\hline 1a (kuoppamiilu) & $\begin{array}{l}\text { Pyöreä, ovaali, nelis- } \\
\text { kanttinen, suorakaide } \\
\text { tai epäsäännöllinen } \\
\text { kuoppa }\end{array}$ & $\begin{array}{l}\text { Norja } \\
\text { Ruotsi } \\
\text { Belgia } \\
\text { Alankomaat } \\
\text { Itävalta } \\
\text { Saksa }\end{array}$ & $\begin{array}{l}\text { 600-1500 jaa. } \\
\text { 1600-1900-luvut jaa. } \\
660-943 \text { jaa; 1040-1260 jaa. } \\
\text { Varhainen keskiaika; suorakai- } \\
\text { teen muotoisen kuoppamiilut } \\
\text { myöhäisrautakaudesta ja myö- } \\
\text { häisroomalaiselle ajanjaksolle } \\
\text { 1200-luvun lopulta 1500-luvun } \\
\text { alkuun jaa. } \\
\text { 200-400-, 500/600- \& } \\
\text { 900/1000-luvut jaa; cal AD } \\
779-945 \text { (2 sigma) }\end{array}$ \\
\hline 2a (tasamaalla) & $\begin{array}{l}\text { Kumpumainen miilun- } \\
\text { pohja korokkeella tai } \\
\text { ilman }\end{array}$ & Saksa & 1700/1800-luku \\
\hline 2b (tasamaalla) & $\begin{array}{l}\text { Pyöreä miilunpohja, } \\
\text { jota ympäröi ojanne tai } \\
\text { useita kuoppia }\end{array}$ & $\begin{array}{l}\text { Belgia } \\
\text { Saksa } \\
\text { Puola }\end{array}$ & $\begin{array}{l}\text { 1700-luku } \\
1400-\text { luvun puolivälistä } 1800-\text { lu- } \\
\text { vun puoliväliin } \\
1400-, 1700-\text { ja } 1800 \text {-luvut }\end{array}$ \\
\hline 2c (tasamaalla) & $\begin{array}{l}\text { Pyöreä miilunpohja } \\
\text { ympärysvallilla }\end{array}$ & $\begin{array}{l}\text { Belgia } \\
\text { Saksa } \\
\text { Norja }\end{array}$ & 1642-1822 (Eidsvollin ruukki) \\
\hline $\begin{array}{l}\text { за (rinteessä, } \\
\text { lamamiilu) }\end{array}$ & Kulmikas miilunpohja & $\begin{array}{l}\text { Itävalta } \\
\text { Ruotsi }\end{array}$ & 1600- tai 1700-luku \\
\hline 3b (rinteessä) & $\begin{array}{l}\text { Pyöreän miilunpohjan } \\
\text { pinta on tasoitettu } \\
\text { rinteeseen }\end{array}$ & $\begin{array}{l}\text { Sveitsi } \\
\text { Saksa } \\
\text { Belgia } \\
\text { Ranska } \\
\text { Irlanti } \\
\text { Connecticut, } \\
\text { Yhdysvallat }\end{array}$ & $\begin{array}{l}\text { 400-1800-luvut } \\
\text { Pääsääntöisesti 1600-luvun } \\
\text { puolivälistä alkaen } \\
\text { 1600-luvun lopusta varhaiselle } \\
\text { 1700-luvulle } \\
\text { 1762-1872 }\end{array}$ \\
\hline 3c (rinteessä) & $\begin{array}{l}\text { Pyöreän miilunpohjan } \\
\text { pinta on tasoitettu } \\
\text { rinteeseen ja sitä ym- } \\
\text { päröi valli }\end{array}$ & Saksa & \\
\hline
\end{tabular}

Taulukko 2. Miilunpohjaluokittelua Hirsch et al:n (2020) mukaan. 


\begin{tabular}{|l|l|l|}
\hline Tyyppi & Kuvaus & Esimerkkikohde \\
\hline Ia (kuoppamiilu) & $\begin{array}{l}\text { Pieni neliskanttinen tai pyöreä } \\
\text { painanne (hiilikuoppa) }\end{array}$ & \\
\hline Ib (kuoppamiilu) & $\begin{array}{l}\text { Suuri (syvä) suorakaiteen muo- } \\
\text { toinen painanne }\end{array}$ & Rautavaara Lapinjärvi Hyttikangas \\
\hline & & \\
\hline Ila (pystymiilu) & Pyöreä kumpu & Rautavaara Hiilimiilukangas \\
\hline Ilb (pystymiilu) & Pyöreä kumpu, kuoppia & Salo Nenustannummi 1 \\
\hline Ilc (pystymiilu) & $\begin{array}{l}\text { Pyöreä kumpu, ojanne (sekä } \\
\text { mahdollisesti kuoppia) }\end{array}$ & Tuusula Grankulla 2 \\
\hline IId (pystymiilu) & Pyöreä ympärysvalli & Rautavaara Jokilampi \\
\hline Illa (lamamiilu) & Suorakaiteen muotoinen kumpu & Kotka Mussalo länsi \\
\hline IIlb (lamamiilu) & $\begin{array}{l}\text { Suorakaiteen muotoinen kumpu, } \\
\text { valli }\end{array}$ & \\
\hline
\end{tabular}

Taulukko 3. Vaihtoehtoinen alustava malli miilunpohjien luokitteluksi.

pohjien välillä. Tästä syystä olisin itse valmis jakamaan ojalliset ja kuopalliset miilunpohjat omiksi alatyypeikseen. On myös kyseenalaista eroavatko rinteeseen ja tasamaalle rakennetut pystymiilut ratkaisevasti toisistaan rakenteensa osalta. Rinteeseen on mahdollista valmistaa tasapohja, samoin kuin lievästi viettävä pohja tasamaalle. Osa pystymiiluista on ollut pohjaltaan viettäviä eli "luisupohjaista" mallia. ${ }^{52}$ Näitä miiluja jaottelu ei kuitenkaan huomioi, enkä osaa arvioida miten yleisiä ne ovat olleet Suomessa saati muualla.

Artikkelin kuoppamiilunpohjille varaama tyyppi 1 käsittää vain yhden alatyypin. 1a on niin pyöreille, suorakulmaisille kuin epäsäännöllisen muotoisille miilupohjille, jotka ovat melko matalia, usein noin $40 \mathrm{~cm}$ syvyydeltään. ${ }^{53}$ Huomattavasti syvempiä ja tilavuudeltaan suurempia kuoppamiiluja Keski-Euroopasta ja Skandinaviasta ei ilmeisesti tällä hetkellä tunneta, eli ne tuskin ovat ainakaan tavallisia. Tältä kansainvälisemmältä kantilta gradussa soveltamani nimeämiskäytäntö ei ole kovinkaan onnistunut.

Kyseisiä suuria miilunpohjia on löydettävissä Pohjois-Savon ja Pohjois-Karjalan suunnalta, mutta toistaiseksi en ole kyennyt paikantamaan niitä muualta Suomesta. Mahdollisuuksia systemaattiseen etsintään minulla ei valitettavasti ole ollut. On toistaiseksi avoin kysymys, onko kyseinen miilunpohjatyyppi tavallinen Suomessa vai vain pohjoisen SavoKarjalan alueella. Kuten jo aiemmin mainitsin, arkeologisen aineiston niukkuudesta huolimatta suuret kuoppamiilut eivät kuitenkaan ole täysin tuntematon ilmiö maailmalla. Hirsch et al:n jaotteluun nämä suuret miilunpohjat ovat helposti lisättävissä uudeksi alatyypikseen.

\footnotetext{
52 Lassila 1914, 21-23.

${ }^{53}$ Hirsch et al. 2020, 976, 977.
} 
Erilaisia jaotteluja on mahdollista muodostaa kriteerejä vaihtelemalla lähes loputtomasti, mutta tällä hetkellä jaottelisin, ainakin Suomen vasta alustavasti hahmottuvaa kokonaisuutta ajatellen, miilunpohjat hieman edellä esitetystä poiketen (Taulukko 3). Jaon tarkoituksena on ensisijaisesti tarjota nopea tapa jäsennellä kyseisen muinaisjäännöstyypin erilaisia piirteitä. Tyyppijaosta voi olla hyötyä myös silloin, kun miilunpohjia pitää kuvailla tiiviisti eli erityisesti inventointikertomuksissa. Huolellisesta kohteen piirteiden dokumentoinnista kannattaa kuitenkin pitää mahdollisuuksien mukaan kiinni, sillä kuten todettua, tästä aiheesta on vielä paljon selvittämättä ja tulkinnat voivat vielä muuttua.

\section{Tutkimuksen suuntia}

Edellä olen pyrkinyt luomaan lyhyen katsauksen miilunpohjiin arkeologisina ilmiöinä ja miilunpolton käytäntöihin. Kïnnostus miilunpolton historiaan on kasvussa, mihin on varmasti vaikuttanut paljon miilunpohjien suuren määrän selkeä erottuminen nykyisin hyvin saatavilla olevasta laserkeilausaineistosta. Kyseisen aineiston tarkastelun seuraava askel on tekoälyalgoritmien hyödyntäminen kohteiden paikantamisessa. Maailmalta tästä on jo joitakin esimerkkejä, mutta ne eivät toistaiseksi ole sovellettavissa ilman perehtymistä ohjelmoinnin saloihin. ${ }^{54}$ Suomessa alkuvuodesta käynnistyneessä LIDARK-hankkeessa tavoitteena on arkeologisten kohteiden automaattinen tunnistaminen tarjolla olevista laserkeilausaineistoista. ${ }^{55}$ Projektin tulokset ovat todennäköisesti helposti sovellettavissa miilunpohjien paikantamiseen.

Oma kysymyksensä on se, onko kaikki miilunpohjat todettava paikan päällä maastotarkastuksessa ennen suojelupäätöksen tekemistä. Laserkeilausaineistossa on tulkinnalliset virhetekijänsä, eikä tekoälykään ole erehtymätön. Toisaalta esimerkiksi nykyisin harjoitettu metsänhoito äestyksineen, laikutuksineen ja mätästyksineen voi vahingoittaa muinaisjäännöstä hyvin äkillisesti. ${ }^{56}$ Päätöstä ei siksi voi lykätä loputtomiin. Jokainen miilunpohja ei ole suojelun arvoinen, mutta alueellisia suojelukokonaisuuksia muodostettaessa on mietittävä, mitä kokonaisuuden halutaan edustavan. Tehdyt päätökset voivat vaikuttaa aiheen myöhempään tulkintaan.

Suomessa miilunpohjien levintää ei ole toistaiseksi kartoitettu. Miilunpohjista saatavilla olleen tiedon vähäisyys on johtanut aiemmin niiden jättämiseen huomiotta tai väärintulkintaan arkeologisten inventointien yhteydessä. Nykyisellään tilanne on kuitenkin parempi ja hiilenpolttoa käsitellään muun muassa Museoviraston Arkeologisen kulttuuriperinnön oppaassa. ${ }^{57}$ Perusta eri miilunpohjatyyppien levinneisyyden kartoittamiselle on olemassa. Tietoa kaivataan myös huonosti tunnettujen tyyppien rakenteista eli ennen muuta suurten kuoppamiilunpohjien ja hiilikuoppien osalta.

\footnotetext{
${ }^{54}$ Esim. Bonhage et al. 2021; opinnäytteistä Wijkhuizen 2018; Anderson 2019.

55 "Arkeologisten kohteiden automaattinen tunnistaminen laserkeilausdatasta", www.oulu.fi/arkeologia/ node/208931.

${ }^{56}$ Menetelmistä lyhyt kuvaus esim. Uotila, Luoranen \& Saksa, www.luke.fi/kehityshyppy/metsanhoitotieto/ maanmuokkaus/.

${ }^{57}$ Arkeologisen kulttuuriperinnön opas, akp.nba.fi 18.9.2020.
} 


\section{Lähdeluettelo}

\section{Tutkimusaineisto}

Maanmittauslaitos (MML) 2021. Laserkeilausaineisto. Viitattu 28.6.2021.

Maanmittauslaitos (MML) 2021. Maastotietokanta. Viitattu 28.6.2021.

\section{Painamattomat lähteet}

Anderson, Eli. 2019. Mapping Relict Charcoal Hearths in the Northeast US Using Deep Learning Convolutional Neural Networks and LIDAR Data. Master's Theses, nro 1387. Geography, University of Connecticut. https://opencommons.uconn.edu/gs_theses/1387.

Kangaskesti, Janne. 2019. Se syntyi sysimäellä, kasvoi hiilikankahalla - hiilimiilujen arkeologiset jäännökset Suomessa. Pro gradu. Arkeologia, Helsingin yliopisto. http://urn.fi/URN:NBN:fi:hulib-201906132728.

Kykyri, Marita. 2010. Kotka, Mussalo, Takakylä Santalahden leirintäalueen laajennus. Hiilimiilujen valvontakaivaus ja dokumentointi. Kaivaus- ja dokumentointikertomus. Kymenlaakson museo.

Lukkarinen, J. 1939. Pohjois-Karjalan kansanomaisesta raudanvalmistuksesta. Pohjois-Karjalan museolle suoritettu stipendiaattityö. Museoviraston arkisto, kansatieteellinen aineisto. KM:Кз०6.

Mönkkönen, Riku. 2012. Rautavaara ja Juuka kulttuuriperintöinventointi 2012. Metsähallituksen asianumero 5795/41/2012. Kansallinen metsäohjelma (KMO) 2015. Metsähallitus.

Rolöf, Magnus ja Katarina Österström. 2007. En medeltida kolningsgrop vid Grebo Prästgård. Förundersökning av UV 4:1, Melskog 1:1 och avgränsning av UV 4:2 UV 4:1 och 4:2, Grebo Prästgård Grebo Socken, Åtvidabergs kommun Östergötland. UV Öst, rapport 2007:40. Riksantikvarieämbetet.

Taivainen, Jouni. 2010. Salo Teijon alue. Kulttuuriperintökohteiden inventointi. Metsähallituksen asianumero 5869/41/2010. Kansallinen metsäohjelma (KMO) 2015. Metsähallitus.

Wennerberg, Rickard. 2008. 1000 år av kolning i Nifsarp. Arkeologisk undersökning av kolningsgropar, liggmila och kolbottnar inför anläggande av ny trafikövningsplats inom fastigheten Nifsarp 1:12. Arkeologisk rapport 2008:17. Jöngköpings läns museum.

Wijkhuizen, Frans. 2018. Relict Charcoal Hearths in the Horstwalde area: Comparing the first Charcoal Hearths found in open fields with hearths found in forest and using historical maps and soil profiles to explain site choosing. Bachelor Theses. University of Amsterdam. http://www.gis-studio.nl/projects/bsc_projects/ Bachelor_Thesis_Frans_Wijkhuizen_UvA_2018.pdf.

\section{Kirjallisuus}

Arpi, G. 1953. "The Supply with Charcoal of the Swedish Iron Industry from 1830 to 1950." Geografiska Annaler, 35 (1): 11-27. https://doi.org/10.2307/520263.

Bergroth, F. G. 1885. Miilunpoltosta. Suomen Metsäyhdistyksen kirjasia III. Helsinki.

Bergström, Hilding ja Gösta Wesslén. 1915. Om träkolning. : P.A Norstedt \& Söner.

Bonhage, Alexander, Mahmoud Eltaher, Thomas Raab, Michael BreuB, Alexandra Raab ja Anna Schneider. 2021. "A modified Mask region-based convolutional neural network approach for the automated detection of archaeological sites on high-resolution light detection and ranging-derived digital elevation models in the North German Lowland." Archaeological Prospection, 28 (2): 177-186. https://doi.org/10.1002/arp.1806.

Ekman, Karl. 1937. Herraskartanon vanhan tehtaan historia. Teijon tehtaat 1686-1936. : Teijon tehtaat osakeyhtiö.

Emrich, Walter. 1985. Handbook of Charcoal Making. Solar Energy R\&D in the European Community. Series E, vol. 7. Energy from Biomass. D. Reidel Publishing Company for the Commission of the European Communities.

FAO. 1983. Simple Technologies for Charcoal Making. FAO Forestry Paper 41. : Food and Agriculture Organization of the United Nations.

Fredman, Per-Olof. 2009. Skog \& historia i Uppsala län. Skogsstyrelsen Rapport 2009:2. Skogsstyrelsen.

Groenewoudt, Bert. 2007. "Charcoal Burning and Landscape Dynamics in the Early Medieval Netherlands." Ruralia, 6: 327-337. Brepols. https://doi.org/10.1484/M.RURALIA-EB.3.1150.

Helander, A. Benj. 1922. Metsänkäyttöoppi. : WSOY.

Hennius, Andreas. 2019. Spår av kolning. Arkeologiskt kunskapsunderlag och forskningsöversikt. Riksantikvarieämbetet. 
Hennius, Andreas, Jonas Svensson, Anna Ölund ja Hans Göthberg. 2005. Kol och tjära. Arkeologi i norra Upplands skogsmarker. Undersökningar för E4. Vendel, Tierp och Tolfta socknar, Uppland. Rapport 2005:02, avdelningen för arkeologiska undersökningar. Uppland: Upplandsmuseet.

Hirsch, Florian, Anna Schneider, Alexander Bonhage, Alexandra Raab, Patrick J. Drohan ja Thomas Raab. 2020. "An initiative for a morphologic-genetic catalog of relict charcoal hearths from Central Europe." Geoarchaeology, 35: 974-983. https://doi.org/10.1002/gea.21799.

Lassila, Vilho. 1914. Miilunpoltto. Helsinki: Keskusmetsäseura Tapio.

Laine, Eevert. 1948. Suomen vuoritoimi 1809-1884 II. Ruukit. Historiallisia Tutkimuksia XXXI, 2. Suomen Historiallinen Seura.

Niukkanen, Marianna. 2009. Historiallisen ajan kiinteät muinaisjäännökset. Tunnistaminen ja suojelu. Museoviraston rakennushistorian osaston oppaita ja ohjeita 3. Museovirasto.

Powell, Alan J, Jane Wheeler ja Cathy M. Batt. 2012. "Identifying archaeological wood stack charcoal production sites using geophysical prospection: magnetic characteristics from a modern wood stack charcoal burn site". Journal of Archaeological Science, 39 (5): 1197-1204. https://doi.org/10.1016/j.jas.2011.11.005.

Roininen, Riitta. 1978. Järvimalminnosto ja kotiraudanvalmistus Rautavaaralla. Rautavaaran kulttuurilautakunnan teettämä haastattelututkimus.

Saloheimo, Veijo. 1953. Nurmeksen historia. Kuopio: Savon sanomat.

Scott, Andrew ja Freddy Damblon. 2010. “Charcoal: Taphonomy and significance in geology, botany and archaeology." Palaeogeography, Palaeoclimatology, Palaeoecology, 291 (1): 1-10. https://doi.org/10.1016/j. palaeo.2010.03.044.

Seppänen, Vilho. 1939. Miilunpoltto. Helsinki: Keskusmetsäseura Tapio.

Talvitie, Y. 1924. Puun hiilto ja hartsin valmistus. Porvoo: WSOY.

Vanhaa Hauhoa. 1934. Kansatieteellinen arkisto 1. Suomen Muinaismuistoyhdistys.

Vilkuna, Kustaa H.J. 1994. Valtakunnan eduksi, isänmaan kunniaksi, ruukinpatruunalle hyödyksi. Suomen rautateollisuus suurvalta-ajalla. Historiallisia Tutkimuksia 188. Suomen Historiallinen Seura.

Vilppo, Teemu, Sari Pitkänen, Markus Melin ja Kirsi Mononen. 2016. “Methods and techniques for efficient charcoal production." Teoksessa Sustainable Fuelwood Management in West Africa, toimittaneet Kirsi Mononen ja Sari Pitkänen: 67-95. Joensuu: University of Eastern Finland.

\section{Verkkosivut}

"Arkeologisten kohteiden automaattinen tunnistaminen laserkeilausdatasta." Oulun yliopisto. Viitattu 11.6.2021. https://www.oulu.fi/arkeologia/node/208931.

Arkeologisen kulttuuriperinnön opas. Museovirasto. Viimeksi muokattu 18.9.2020. Viitattu 30.6.2021. http:// akp.nba.fi/.

"Historialliset ilmakuvat." Paikkatietoikkuna. Maanmittauslaitos. 1.6.2021. Viitattu 29.6.2021. https://kartta. paikkatietoikkuna.fi/.

Kielitoimiston sanakirja. 2020. Kotimaisten kielten keskus ja Kielikone Oy. Helsinki. URN:NBN:fi:kotus-201433. Verkkojulkaisu HTML. Päivitettävä julkaisu. Viitattu 28.6.2021. https://www.kielitoimistonsanakirja.fi.

Uotila, Karri, Jaana Luoranen ja Timo Saksa. "Maanmuokkaus - mätästys, äestys \& laikutus." Kehityshyppy metsänhoitoon -hanke. Luonnonvarakeskus. Viitattu 30.6.2021. https://www.luke.fi/kehityshyppy/metsanhoitotieto/maanmuokkaus/. 